\title{
Does Water Quality Affect the Plankton Dynamics and the Specific Growth Rate of Litopenaeus vannamei?
}

\author{
Muhammad Musa ${ }^{1,2^{*}}$, Sulastri Arsad ${ }^{1,2,3}$, Mohammad Mahmudi ${ }^{1,2}$, \\ Evellin Dewi Lusiana ${ }^{1,2}$, Naura Khansa Agharid ${ }^{1}$, Selvi Darmayanti', \\ Fiddy Semba Prasetiya ${ }^{4}$
}
${ }^{1}$ Department of Aquatic Resources Management, Faculty of Fisheries and Marine Science, Universitas Brawijaya, Jl. Veteran Malang 65145, Indonesia
${ }^{2}$ Aquatic Resources and Ecological Research Group (AquaRES), Faculty of Fisheries and Marine Science, Universitas Brawijaya, Jl. Veteran Malang 65145, Indonesia
${ }^{3}$ Microbiol Resources and Technology (MicroBase) Group, Post-graduate Program Universitas Brawijaya, Jl. Veteran Malang 65145, Jawa Timur Indonesia
${ }^{4}$ Marine Science Department, Faculty of Fisheries and Marine Sciences, Universitas Padjadjaran, J1. Raya Bandung Sumedang KM.21, Jatinangor 45363, Indonesia

Received: 12 August 2020

Accepted: 31 October 2020

\begin{abstract}
The whiteleg shrimp Litopenaeus vannamei is one of the most cultured penaeid species in Indonesia. However, a good standard of environment such as water quality characteristics for aquaculture must be met to avoid commercial loss. The aims of the study were to analyze the water quality in the aquaculture pond and their relationship with plankton dynamics and specific growth rate (SGR) of L. vannamei. A descriptive method with the analysis on the primary and the secondary data was performed to determine the effect of water quality on the abundance of plankton and the SGR of the whiteleg shrimp in the intensive pond. The results showed that the plankton abundance indicates that the pond is eutrophic and the water quality affects the plankton abundance. The regression analysis demonstrated that the abundance of phytoplankton was influenced (from the highest to the lowest regression coefficient) by the salinity $(94.7 \%)$, orthophosphate $(94.1 \%)$, temperature $(91.8 \%), \mathrm{CO}_{2}$ $(80.3 \%)$, turbidity (66.1\%), total organic matter (TOM, 35.2\%) and ammonia (16.4\%). On the other hand, the zooplankton abundance was significantly affected by the temperature (44.7\%), turbidity (41.9\%), dissolved oxygen (DO, 26.2\%), salinity (14.9\%) and TOM (7.2\%). The parameters of water quality that affect SGR L. vannamei were ammonia (87.3\%), zooplankton abundance (81.2\%), TOM (74.9\%), DO (63.1\%), pH (48.9\%), temperature (41\%), turbidity (25.8\%), salinity $(19.4 \%)$, orthophosphate $(13.2 \%)$,
\end{abstract}

*e-mail: musa_fpi@ub.ac.id 
and phytoplankton abundance (1.1\%). The PCA analyses performed the relation between plankton abundance and water quality parameters.

Keywords: aquaculture, plankton dynamic, vannamei shrimp, water quality

\section{Introduction}

Aquaculture is one of the solutions to increase fisheries production in worldwide. The aquaculture activity requires the cultured animals and the media where these cultured animals can live. One of the most common shrimp aquacultures in Indonesia is the farming of whiteleg shrimp Litopenaues vannamei [1]. This species has been considered as one of the most commercially important due to its high return. Aquaculture shrimp ponds has been extensively increased over time, especially from the aspect of management to increase the production. Recently, an intensive management system has been often being applied. An intensive aquaculture is characterized by periodic monitoring in the shrimp ponds to produce a high quality of shrimp [2].

Continuous aquaculture activities may significantly affect the environment, which is indicated by water quality degradation. A good management practice of shrimp ponds will lead to a good water quality that support the growth of plankton. High diversity of plankton with high abundance within species will maintain the water quality and increase the productivity of shrimp ponds [3]. Furthermore, good management of water quality in intensive shrimp aquaculture can enhance the water quality parameters, thus supporting the growth of L. vannamei [4]. The growth rate of L. vannamei is also influenced by feed supply, fertilizing as well as aeration [5]. This fact shows that water quality in the shrimp ponds can affect the presence of plankton and the growth of L. vannamei, where the plankton abundance can reflect the water condition and $L$. vannamei obsolete growth can be used as an indicator of success in the aquaculture system. This study aimed to measure water quality in shrimp ponds and determine their relationship to plankton dynamics and growth of L. vannamei.

\section{Materials and Methods}

Descriptive method was performed by collecting water quality data such as temperature, transparency, $\mathrm{pH}$, dissolved oxygen (DO), carbon dioxide $\left(\mathrm{CO}_{2}\right)$, salinity, ammonia $\left(\mathrm{NH}_{4}-\mathrm{N}\right)$, total organic matter (TOM), nutrient in form of nitrate $\left(\mathrm{NO}_{3}\right)$ and orthophosphate $\left(\mathrm{PO}_{4}\right)$, plankton abundance and their biological index (diversity, evenness and dominancy) were measured either in situ or ex situ in the laboratory. The relationship between water quality parameters and plankton abundance as well as specific growth rate of $L$. vannamei was analyzed using simple regression.

\section{Diversity Index}

The diversity index was measured by using Shannon-Wiever index [6] by following formula:

$$
H^{\prime}=-\sum P i \ln (P i)
$$

Where $P i=n i / N$

...where $\mathrm{H}^{\prime}$ is diversity index, ni is number of species -i, and $\mathrm{N}$ is the total number of species.

\section{Evenness Index}

The evenness index was measured by the following formula [7]:

$$
E=\frac{H^{\prime}}{\mathrm{H} \max }
$$

...where $\mathrm{E}$ is evenness, $\mathrm{H}^{\prime}$ is diversity index, and $\mathrm{H}$ max is $\ln \mathrm{S}$, while $\mathrm{S}$ is the total of species.

\section{Dominancy Index}

The dominancy index describes about the dominancy of biotic organisms in ecological community. It could be determined by using formula [8]:

$$
\mathrm{D}=\sum\left(\frac{\mathrm{ni}}{\mathrm{N}}\right)^{2}
$$

...where $\mathrm{D}$ is dominancy index, ni is total individual -i, and $\mathrm{N}$ is total number of all species.

\section{Time and Site of Study}

The present study was conducted during the rainy season from December 2019 to January 2020 in the intensive shrimp aquaculture facility (Lab Lapang Perikanan Air Payau dan Laut) in Probolinggo, East Java, Indonesia. Study site was situated at one intensive shrimp pond facility (Fig. 1) and the pond area is $1600 \mathrm{~m}^{2}$ and the shrimp density is 190 ind. $\mathrm{m}^{2}$ with intensive culture system. samples were collected at three different depth (surface (0.6-0.9 m), middle (0.3-0.6 m) and bottom $(0-0.3 \mathrm{~m})$ of pond). The three depths were determined by measuring the pond depth using AAQ. 


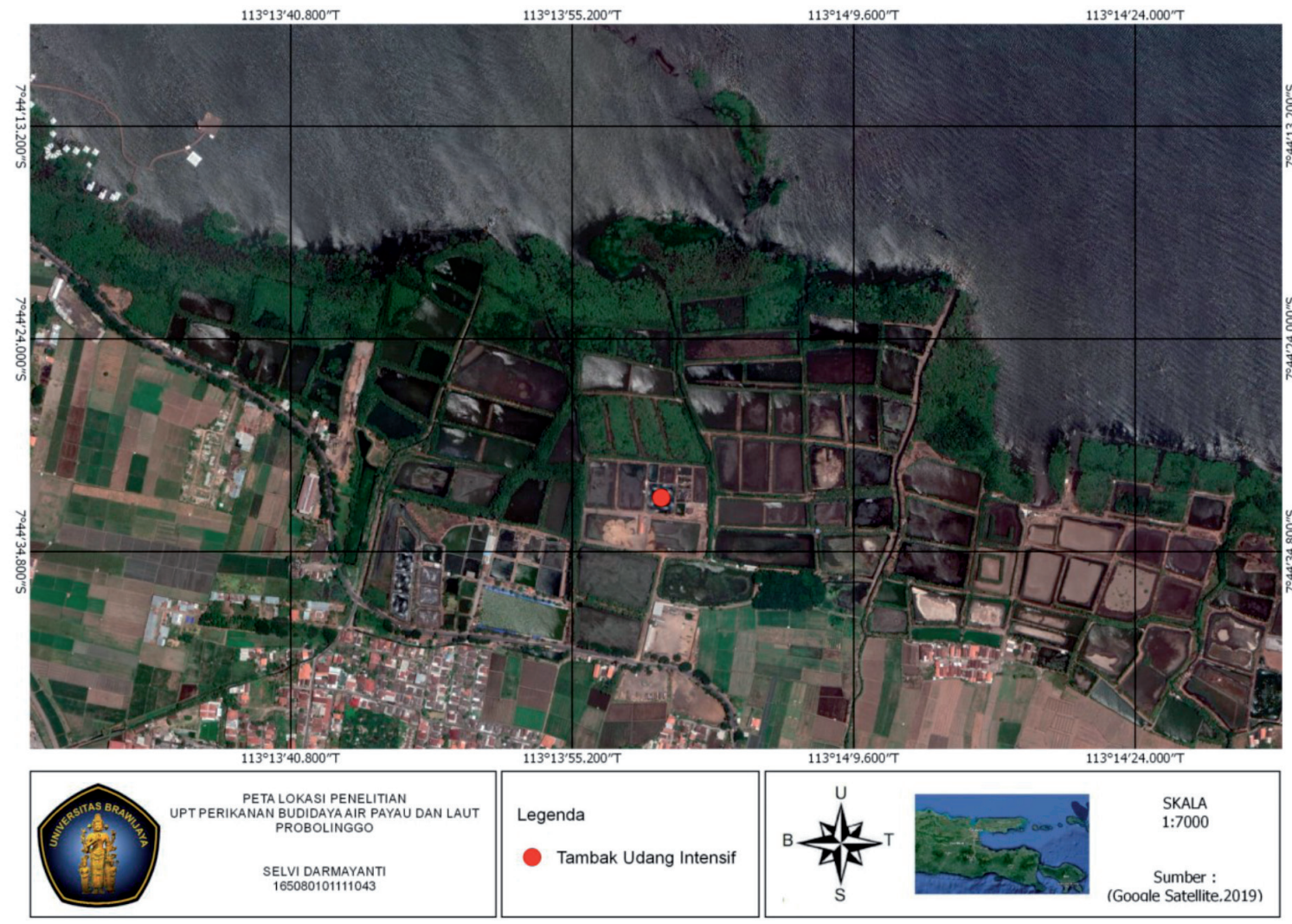

Fig. 1. Map of sampling point.

Three water samples were taken via anco bridge at 11.00-13.00 Western Indonesian Time (WIB) fortnightly with four replicates at each depth $(\mathrm{N}=12$ samples). Water quality measurement and plankton analysis were conducted in the field laboratory Probolinggo, Laboratory of Hidrobiology, Environmental and Aquatic Biotechnology, Faculty of Fisheries and Marine Sciences, Universitas Brawijaya.

\section{Sample Collection}

Measurement on water quality was conducted in situ. Temperature, $\mathrm{pH}, \mathrm{DO}$, and salinity were measured using Aqua Quality Sensor equipment (AAQ Rinko 1183), while $\mathrm{NO}_{3}$ and $\mathrm{NH}_{4}-\mathrm{N}$ were measured using test kit (Nitrate Test Kit Hanna Instrument model: HI 3874 and Ammonia Test Kit Hanna Instrument model: HI 38049). Transparency was measured using Secchi disk. Moreover, other water samples were collected for $e x$ situ analysis that encompassed orthophosphate, $\mathrm{CO}_{2}$ and TOM using $600 \mathrm{ml}$ bottle samples then further analyzed in the laboratory. Orthophosphate measurements were carried out by the spectrophotometer method, while the measurement of $\mathrm{CO}_{2}$ and TOM was carried out by the titration method.

\section{Plankton and L. vannamei Sampling}

Plankton samples were collected using plankton net with mesh size $25 \mu \mathrm{m}$. The obtained samples were placed into the labeled sample bottles (vol. $28 \mathrm{ml}$ ) then lugol $1 \%$ was added into these sample bottles as much as 1-2 drops to preserve the sample. Samples were then added into the cool box and brought into the laboratory for further analysis. Plankton samples were identified morphologically using Prescott (1978) and Davis (1995) identification key. L. vannamei was obtained using a casting net, then 10 individuals of vannamei shrimp were placed into the chamber for further weight measurement. The shrimp samples were air-dried prior to weighting with analytical scales (accuracy $0.01 \mathrm{~g}$ ). Afterward, shrimp samples were re-placed into the experimental chamber.

\section{Data Analysis}

A simple linear regression analysis was performed to determine the effect of water quality on the density of plankton and specific growth rate (SGR) of $L$. vannamei, by using formula as follows:

$$
Y=a+b X
$$

...where $Y$ is the density of plankton (cell $\mathrm{ml}^{-1}$ ) and/or SGR of $L$. vannamei (\%), $a$ and $b$ are the constants and $X$ is the water quality parameters. 


\section{Results and Discussion}

\author{
Water Quality
}

Temperature

In the present study, temperature ranged from 29.76 to $32.95^{\circ} \mathrm{C}$ (Table 1 ). The temperature in this study is in accordance to the standard for the maintenance of $L$. vannamei for intensive aquaculture, which is $>27^{\circ} \mathrm{C}$ [9]. Fluctuation in temperature on each observation could be due to the weather factor during the measurement in the shrimp ponds. A decrease in temperature may occur because of the rainfall during the sample collections, that lead to temperature decline [10].

\section{Transparency}

The transparency in this study ranged from 16.55 to $25.5 \mathrm{~cm}$. This value was lower than the transparency value suggested by the standard for the maintenance of L. vannamei for intensive aquaculture, which ranged from 30 to $50 \mathrm{~cm}$ [9]. This low transparency value may alter light penetration into the shrimp ponds. This is probably due to the slow water circulation, which allows accumulation of feed waste and fecal pellets. These accumulated wastes may be brought up to the water surface that alter water transparency.

$$
p H
$$

In this study, $\mathrm{pH}$ ranged from 7.96 to 9.46 . This value appeared to be higher than the suggested $\mathrm{pH}$ for the standard regulation in L. vannamei intensive aquaculture (7.5-8.5) [9]. Higher $\mathrm{pH}$ can be caused by the feed wastes and fecal pellets that can increase $\mathrm{pH}$. Conversely, low $\mathrm{pH}$ may occur due to the water supply from the reservoir and the water input from the rainfall into the shrimp ponds. However, decrease in $\mathrm{pH}$ did not occur spontaneously and did not affect the productivity of the ponds [10].

Table 1 . Water quality parameters obtained from the study.

\begin{tabular}{|c|c|c|}
\hline No. & Parameters & Value \\
\hline 1. & Temperature $\left({ }^{\circ} \mathrm{C}\right)$ & $29.76-32.95$ \\
\hline 2. & Salinity $(\mathrm{ppt})$ & $16.06-27.42$ \\
\hline 3. & $\mathrm{pH}$ & $7.97-9.46$ \\
\hline 4. & $\mathrm{DO}\left(\mathrm{mg} \mathrm{l}^{-1}\right)$ & $6.18-6.82$ \\
\hline 5. & Transparency $(\mathrm{cm})$ & $16.55-25.5$ \\
\hline 6. & $\mathrm{NO}_{3}\left(\mathrm{mg} \mathrm{l}^{-1}\right)$ & $0-10$ \\
\hline 7. & $\mathrm{NO}_{2}\left(\mathrm{mg} \mathrm{l}^{-1}\right)$ & $0-0.2$ \\
\hline 8. & $\mathrm{NH}_{4}-{\mathrm{N}\left(\mathrm{mg} \mathrm{l}^{-1}\right)}^{0.6-3}$ \\
\hline 9. & \left.${\mathrm{TOM}\left(\mathrm{mg} \mathrm{l}^{-1}\right)}_{4}\right)$ & $5.05-40.44$ \\
\hline 10. & $\mathrm{PO}_{4}\left(\mathrm{mg} \mathrm{l}^{-1}\right)$ & $0.085-0.167$ \\
\hline
\end{tabular}

\section{Dissolved Oxygen (DO)}

DO in this study ranged from 6.18-6.92 $\mathrm{mg} \mathrm{l}^{-1}$, which is incongruent with the standard that falls on $\geq 4 \mathrm{mg} \mathrm{l}^{-1}$, for the shrimp intensive aquaculture [9]. The obtained DO can be influenced by the sampling time. High content of DO generally found because the sampling was performed on the day light, this is probably due to photosynthesis from the phytoplankton that can increase DO in the ponds [10].

\section{Carbon Dioxide $\left(\mathrm{CO}_{2}\right)$}

$\mathrm{CO}_{2}$ in the shrimp ponds ranged from 16.96-33.88 $\mathrm{mg} \mathrm{l}^{-1}$. The optimum $\mathrm{CO}_{2}$ to support plankton growth in the aquatic environment is $12 \mathrm{mg} \mathrm{l}^{-1}$ thus photosynthesis can occur without any alteration [11]. In the present study, the obtained $\mathrm{CO}_{2}$ is slightly above the optimum value to support plankton growth, however, this amount is still can be tolerated by them in the shrimp ponds. Higher $\mathrm{CO}_{2}$ in the aquatic environment could be due to diffusion of this gas from the air into the water body and also as the consequence of respiration from the aquatic organisms. Additionally, $\mathrm{CO}_{2}$ in the aquatic environment can be produced from the decomposition of organic materials by bacteria [12].

\section{Salinity}

The range of salinity in this study was from 16.06-27.42 ppt. This value is lower than the standard value for the L. vannamei intensive aquaculture, which ranges from 28 to $32 \mathrm{~g} \mathrm{l}^{-1}$ [9]. The source of the water used to irrigate the ponds comes from the reservoir. where, this reservoir holds water from the sea which is then given fresh water input. This is done to obtain water with a salinity suitable for the cultivation of L.vannamei. Higher salinity may occur due to high temperature during the sampling time that provokes an intense evaporation. As a consequence, the salt content will increase thus increasing salinity. In contrast, lower salinity may be caused by the rainfall during the sampling time that dilutes the salt content in the ponds, thus salinity will decrease due to high freshwater supply [10].

$$
\text { Ammonia }\left(\mathrm{NH}_{4}-\mathrm{N}\right)
$$

The observed $\mathrm{NH}_{4}-\mathrm{N}$ in this study ranged from 0.6 to $3 \mathrm{mg} \mathrm{l}^{-1}$. The obtained value is slightly higher than the suggested in the quality standard in L. vannamei intensive aquaculture $\left(\leq 0.1 \quad \mathrm{mg} \mathrm{l}^{-1}\right) \quad$ [9]. Higher concentration of $\mathrm{NH}_{4}-\mathrm{N}$ indicates higher decomposition of organic materials in the shrimp ponds. In the aquatic environment, $\mathrm{NH}_{4}-\mathrm{N}$ could be toxic to the aquatic organisms when the concentration is higher than $1 \mathrm{mg} \mathrm{l}^{-1}$. Nevertheless, this can be altered by high amount of oxygen that will oxidize $\mathrm{NH}_{4}-\mathrm{N}$ into $\mathrm{NO}_{3}$, which is less toxic for the aquatic organisms [13]. 


\section{Total Organic Matter (TOM)}

In the present study, TOM ranged from 5.06-40.45 $\mathrm{mg} \mathrm{l}^{-1}$. This range is in accordance with the standard quality for the L. vannamei intensive aquaculture $\left(\leq 90 \mathrm{mg} \mathrm{l}^{-1}\right)$ [9]. Reduction on TOM in the ponds is probably caused by the rainfall during the sampling thus the organic materials in the ponds were diluted by the water supply from the rainfall [14]. Additionally, the increase value on TOM could be influenced by the wastes input such as uneaten shrimp feed and the produced fecal pellets [15].

\section{Nitrate $\left(\mathrm{NO}_{3}\right)$}

In this study, $\mathrm{NO}_{3}$ was found at range from 0 to $10 \mathrm{mg} \mathrm{l}^{-1}$. This range is the lowest range in the $\mathrm{NO}_{3}$ test kit. To our knowledge, $\mathrm{NO}_{3}$ is not toxic for the shrimp at concentration lower than $50 \mathrm{mg} \mathrm{l}^{-1}$. $\mathrm{NO}_{3}$ is the main form of nitrogen in the natural aquatic environment and highly required by the algae growth, due to its stability and solubility [16].

\section{Nitrite $\left(\mathrm{NO}_{2}\right)$}

The $\mathrm{NO}_{2}$ is the product of oxidation from ammonia [17]. The $\mathrm{NO}_{2}$ found in this study ranged from 0 to $0.2 \mathrm{mg} \mathrm{l}^{-1} . \mathrm{NO}_{2}$ content in an intensive $L$. vannamei aquaculture ponds according to the standard quality is should be $\leq 1 \mathrm{mg} \mathrm{l}^{-1}$ [9]. Our results demonstrate that $\mathrm{NO}_{2}$ found in this study is in accordance with the standard
Orthophosphate $\left(\mathrm{PO}_{4}\right)$

The $\mathrm{PO}_{4}$ found in this study ranged from 0.085 to $0.167 \mathrm{mg} \mathrm{l}^{-1}$. This value is still in the range of the standard water quality for an intensive $L$. vannamei aquaculture $\left(0.1-5 \mathrm{mg} \mathrm{l}^{-1}\right)$ [9]. Decrease of $\mathrm{PO}_{4}$ in the aquatic environment could be due to the utilization or take up by the algae, phytoplankton, macrophyte and bacteria [18].

\section{Plankton}

\section{Plankton Abundance}

The abundance of phytoplankton in this study was from $2,576 \times 10^{3}$ to $6,020 \times 10^{3}$ cells $\mathrm{ml}^{-1}$. Whereas the abundance of zooplankton ranged from 280 to 1624 ind $1^{-1}$ (Table 2). Morphological analysis on plankton demonstrate that there were 5 classes of phytoplankton in the shrimp pond. These 5 classes were from the Chlorophytes (4), Chrysophytes (2) and Cyanophytes (1) (Table 2). On the other hand, the zooplankton were consisting of Rotifers (1) and Arthropods (2) (Table 2). The variation in plankton abundance could be due to weather during the sampling. In phytoplankton, their abundance was influenced by the weather and the presence of activities surrounding the sampling point and also the change in water quality parameters [19]. Total abundance of phytoplankton from the present study indicates that the shrimp pond is in eutrophic with the total abundance

Table 2. Plankton abundance.

\begin{tabular}{|c|c|c|c|c|c|c|}
\hline \multicolumn{7}{|c|}{ Abundance of phytoplankton (cell ml $\mathrm{ml}^{-1}$ ) } \\
\hline \multirow{2}{*}{ Division } & \multirow{2}{*}{ Genus } & \multicolumn{4}{|c|}{ Sampling time } & \multirow{2}{*}{ Number } \\
\hline & & 1 & 2 & 3 & 4 & \\
\hline \multirow{4}{*}{ Chlorophytes } & Actinastrum & 0 & 0 & 28 & 0 & $28^{*}$ \\
\hline & Gloeocystis & $588^{*}$ & $112 *$ & $308 *$ & $168 *$ & $1,176^{*}$ \\
\hline & Schizomeris & $588 *$ & 0 & 0 & 0 & $588^{*}$ \\
\hline & Sphaerocystis & $1,792 *$ & $1064 *$ & $532 *$ & $700 *$ & $4,088 *$ \\
\hline \multirow{2}{*}{ Chrysophytes } & Cyclotella & $1,064 *$ & $560^{*}$ & $644^{*}$ & $980 *$ & $3,248^{*}$ \\
\hline & Cymbella & $896^{*}$ & $616^{*}$ & $672 *$ & $476^{*}$ & $2,660 *$ \\
\hline Cyanophytes & Chroococcus & $1,092 *$ & $812^{*}$ & $448^{*}$ & $252 *$ & $2,604 *$ \\
\hline \multicolumn{2}{|c|}{ Total abundance of phytoplankton } & $6,020^{*}$ & $3,164^{*}$ & $2,632 *$ & $2,576^{*}$ & $14,952 *$ \\
\hline \multicolumn{7}{|c|}{ Abundance of Zooplankton (ind $1^{-1}$ ) } \\
\hline Rotifers & Brachionus & 280 & 1,624 & 504 & 588 & 2,996 \\
\hline \multirow{2}{*}{ Arthropods } & Nauplius & 0 & 0 & 28 & 336 & 364 \\
\hline & Cyclops & 0 & 0 & 0 & 280 & 280 \\
\hline \multicolumn{2}{|c|}{ Total abundance of Zooplankton } & 280 & 1,624 & 532 & 1,204 & 3,640 \\
\hline
\end{tabular}

Source: analyzed data (2020)

Note $*=$ multiplied by $10^{3}$ 
Table 3. Biological index.

\begin{tabular}{|c|c|c|c|}
\hline Sampling time & $\begin{array}{c}\text { Diversity } \\
\text { Index (H') }\end{array}$ & $\begin{array}{c}\text { Evenness } \\
\text { Index (E) }\end{array}$ & $\begin{array}{c}\text { Dominant } \\
\text { Index (D) }\end{array}$ \\
\hline 1 & 1.820 & 0.336 & 0.179 \\
\hline 2 & 1.605 & 0.312 & 0.224 \\
\hline 3 & 1.833 & 0.388 & 0.170 \\
\hline 4 & 1.940 & 0.395 & 0.161 \\
\hline
\end{tabular}

of phytoplankton was more than 15,000 cells $1^{-1}$. The obtained total abundance of zooplankton also indicates that the shrimp pond is in eutrophic status with total

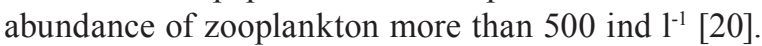

The presence of these plankton probably came from the water source to irrigate the shrimp ponds (influenced by the neap and tides), considering this type of pond is an intensive shrimp pond that really relies on artificial feeds instead of the natural feed from the plankton. Therefore, the function of plankton in the shrimp pond is not as natural feed but they are used to control the water quality in the shrimp pond to absorb the toxic substance in the pond and to produce oxygen apart from the paddle wheel.

\section{Biological Index}

The Shannon-Wiener diversity index (H') in the present study ranged from 1.61-1.94 (Table 3). The diversity of plankton reflects the living structure and can easily analyze the information regarding the species and the abundance of plankton [21]. According to the Shannon-Wiever criteria, the $\mathrm{H}^{\prime}$ in the shrimp ponds can be categorized as moderately diverse, which means that the distribution of individual and the community structure is in moderate condition.

The evenness index (E) is used to identify how much the similarity of distribution for certain individual at each genus on community level [22]. The E value in the present study ranged from 0.31 to 0.395 (Table 3 ). This result demonstrates that the evenness in the shrimp pond is very low in a population, or, the evenness of the organisms is unbalanced. When the value of $E$ is closer to 0 , it means that the evenness between species in the community is very low or vice versa. In contrast, $\mathrm{E}$ value closer to 1 means that the evenness between species is equal [23].

The dominance index (D) was used to determine if there is one dominant species in a population of plankton [21]. The D value in the present study ranged from 0.16 to 0.22 . According to the criteria in the Simpson Dominance Index, the obtained D value can be categorized as low dominance index. When the $\mathrm{D}$ value is closer to 1 , the dominance index is we can interpret that there is a high dominancy and vice versa. Lower D value demonstrates that there is low dominancy or there is no species that dominate others in a community [24].

\section{Specific Growth Rate (SGR)}

The SGR analysis demonstrates that there was a significant growth rate of $L$. vannamei in the shrimp pond. The SGR value obtained from the sampling 1-2, 2-3 and 3-4 were 5.45, 3.88, and 6.05, respectively. The value of SGR varies because the calculation of SGR is done every two weeks. This is done to determine the growth of plankton in that time period. A good stocking density may be defined when the high density of shrimp in a pond is applied, yet the competition for food and space could be tolerated by the animals. Hence the survival rate and the growth rate of the cultured animals are still high, as well as low variation in size for the animals [25].

\section{Food Conversion Ratio (FCR)}

In the present study, the FCR values on the $1^{\text {st }}$ and $2^{\text {nd }}$ sampling time were 1.21 and 1.19 , respectively. These results show that when the feed conversion is large, the feed is not efficiency utilized by the animals. On the other hand, FCR values for the $3^{\text {rd }}$ and $4^{\text {th }}$ sampling were 0.67 and 0.50 , respectively. In general, the FCR value in vanamei ponds ranges from 1.4-1.8. FCR is good if the value is low. By knowing the FCR value, farmers can minimize costs [1]. These low FCR values demonstrate that the feed given is efficiently utilized by the animals for their growth. Previous study by [26] showed that the FCR ratio depends on the protein content on the feed. An appropriate amount of protein in the feed for the shrimps with respect to their nutrition needs will lead to an efficient feeding. Additionally, apart from the amount of feed given, less amount feed given leads to a better FCR.

\section{Relationship between Water Quality and Plankton Abundance}

\section{Phytoplankton}

In the present study, a simple regression between the temperature $(\mathrm{X})$ and phytoplankton abundance $(\mathrm{Y})$ resulted regression equation $\mathrm{Y}=27.51+0.09 \mathrm{x}$, with $\mathrm{R}^{2}$ value of 0.918 , which means that the temperature contributes significantly to the phytoplankton abundance as much as $91.8 \%$. Hence according to this regression equation, an increase in each unit of temperature leads to an increase of phytoplankton abundance as much as 0.089 unit of abundance. Our result also indicates that the temperature in the shrimp pond tend to be high, probably because the weather during the sampling time was sunny and clear. High temperature can favor the growth of phytoplankton in the aquatic environment [27]. Therefore, water temperature contributes significantly to the growth of phytoplankton [28].

The regression equation between the transparency (X) and phytoplankton abundance (Y) in this study was $\mathrm{Y}=13.046+0.199 \mathrm{x}$, with $\mathrm{R}^{2}=0.661$, which 
means that the transparency contributes significantly to the phytoplankton abundance as much as $66.1 \%$. Additionally, this regression equation also implies that every increase in one unit of transparency leads to an increase of phytoplankton abundance by 0.199 unit. High value of transparency significantly affects the photosynthesis that favors the growth of phytoplankton. Conversely, low transparency value significantly affects the distribution and abundance of phytoplankton [29].

The regression analysis between the $\mathrm{CO}_{2}(\mathrm{X})$ and the phytoplankton abundance $(\mathrm{Y})$ was described with the equation $\mathrm{Y}=34.892-0.297 \mathrm{x}$. The obtained $\mathrm{R}^{2}$ was 0.803 , which means that the $\mathrm{CO}_{2}$ contributes significantly to the phytoplankton abundance as much as $80.3 \%$. The obtained regression equation explains that every increase of one unit of $\mathrm{CO}_{2}$ leads to an increase in phytoplankton abundance as much as 0.297 unit. This equation also shows that $\mathrm{CO}_{2}$ was negatively correlated to the phytoplankton abundance. A lower $\mathrm{CO}_{2}$ concentration in the aquatic environment leads to a higher DO concentration and vice versa. This condition will affect the abundance of phytoplankton; thus, a higher $\mathrm{CO}_{2}$ concentration leads to a lower DO concentration that will eventually lead to lower abundance of phytoplankton [30].

The obtained regression equation between salinity (X) and phytoplankton abundance (Y) was $\mathrm{Y}=9.281+0.305 \mathrm{x}$ with $\mathrm{R}^{2}=0.947$. This means that salinity contributes significantly to the phytoplankton abundance as much as $94.7 \%$. According to this equation, it can be explained that with every increase of one unit of salinity, the abundance of phytoplankton will increase by 0.305 units. Additionally, the equation also implies that salinity is positively correlated to the phytoplankton abundance. A higher salinity in the aquatic environment may be caused by evaporation. High intensity of evaporation will lead to higher salinity and it is highly possible that certain species of phytoplankton could not cope with this condition due to their limited adaptation ability [27].

The regression analysis between the $\mathrm{NH}_{4}-\mathrm{N}(\mathrm{X})$ and the phytoplankton abundance $(\mathrm{Y})$ was described with the equation $\mathrm{Y}=2.377-0.024 \mathrm{x}$. The obtained $\mathrm{R}^{2}$ was 0.164 , which means that the $\mathrm{NH}_{4}-\mathrm{N}$ contributes significantly to the phytoplankton abundance as much as $16.4 \%$. The obtained regression equation explains that every increase of one unit of $\mathrm{NH}_{4}-\mathrm{N}$ leads to a decrease in phytoplankton abundance as much as 0.024 unit. This equation also shows that the $\mathrm{NH}_{4}-\mathrm{N}$ negatively correlated with the phytoplankton abundance. This result is in accordance with the study from [31] who demonstrate that a higher concentration of $\mathrm{NH}_{4}-\mathrm{N}$ leads to a depletion of phytoplankton abundance.

The obtained regression equation between TOM (X) and phytoplankton abundance (Y) was $\mathrm{Y}=21.901$ $-0.228 \mathrm{x}$ with $\mathrm{R}^{2}=0.352$. This means that salinity contributes significantly to the phytoplankton abundance as much as $35.2 \%$. According to this equation, it can be explained that every increase of one unit of TOM, the abundance of phytoplankton will decrease by 0.228 units. Additionally, the equation also implies that TOM is negatively correlated to the phytoplankton abundance. This result confirms the previous study from [32] who revealed that a higher concentration of TOM leads to a lower abundance of phytoplankton in the aquatic environment.

The obtained regression equation between $\mathrm{PO}_{4}$ (X) and phytoplankton abundance $(\mathrm{Y})$ was $\mathrm{Y}=0.074$ $+0.001 \mathrm{x}$ with $\mathrm{R}^{2}=0.941$. This means that $\mathrm{PO}_{4}$ contributes significantly to the phytoplankton abundance as much as $94.1 \%$. According to this equation, it can be explained that every increase of one unit of $\mathrm{PO}_{4}$, the abundance of phytoplankton will increase by 0.001 units. Additionally, the equation also implies that $\mathrm{PO}_{4}$ is positively correlated to the phytoplankton abundance. This result confirms the previous study from [33] who revealed that a higher concentration of $\mathrm{PO}_{4}$ leads to a higher abundance of phytoplankton in the aquatic environment. This is because $\mathrm{PO}_{4}$ is the macronutrient that is required for the growth of phytoplankton.

\section{Zooplankton}

In the present study, the regression analysis between the temperature $(\mathrm{X})$ and the zooplankton abundance $(\mathrm{Y})$ was described with the equation $\mathrm{Y}=32.203-0.165 \mathrm{x}$. The obtained $\mathrm{R}^{2}$ was 0.447 , which means that the temperature contributes significantly to the zooplankton abundance as much as $44.7 \%$. The obtained regression equation explains that every increase of one unit of temperature leads to a decrease in zooplankton abundance as much as 0.165 unit. Indeed, temperature is the limiting factor for the aquatic organisms, including the zooplankton. The increase in temperature will enhance metabolism in the aquatic organisms that require more oxygen, that will eventually affect the abundance of zooplankton [34].

The obtained regression equation between transparency (X) and zooplankton abundance (Y) was $\mathrm{Y}=24.032-0.421 \mathrm{x}$ with $\mathrm{R}^{2}=0.419$. This means that transparency contributes significantly to the phytoplankton abundance as much as $41.9 \%$. According to this equation, it can be explained that every increase of one unit of transparency, the abundance of zooplankton will decrease by 0.421 unit. Thus, a low transparency will lead to higher abundance of zooplankton and vice versa. This result is in congruent with [35], because zooplankton is characterized by their negative phototaxis ability.

The obtained regression equation between $\mathrm{pH}$ (X) and zooplankton abundance $(\mathrm{Y})$ was $\mathrm{Y}=8.909$ - $0.038 \mathrm{x}$ with $\mathrm{R}^{2}=0.132$. This means that $\mathrm{pH}$ contributes significantly to the zooplankton abundance as much as $13.2 \%$. According to this equation, it can be explained that every increase of one unit of $\mathrm{pH}$, the abundance of zooplankton will increase by 0.038 unit. A low abundance of zooplankton could be due to the 
low $\mathrm{pH}$ value, where their growth was altered by the acidic condition as demonstrated in [36].

The regression analysis between the DO (X) and the zooplankton abundance (Y) was described with the equation $\mathrm{Y}=6.415+0.028 \mathrm{x}$. The obtained $\mathrm{R}^{2}$ was 0.262, which means that the DO contributes significantly to the zooplankton abundance as much as $26.2 \%$. The obtained regression equation explains that every increase of one unit of $\mathrm{CO}_{2}$ leads to an increase in phytoplankton abundance as much as 0.028 unit. Indeed, DO affects the abundance of zooplankton. Low DO could lead to the depletion of zooplankton abundance. DO is highly required by the zooplankton for their respiration process [34].

The obtained regression equation between salinity (X) and zooplankton abundance (Y) was $\mathrm{Y}=23.205$ $-0.322 \mathrm{x}$ with $\mathrm{R}^{2}=0.149$. This means that salinity contributes significantly to the zooplankton abundance as much as $14.9 \%$. According to this equation, it can be explained that every increase of one unit of salinity, the abundance of zooplankton will decrease by 0.322 units. Additionally, the equation also implies that salinity is negatively correlated to the zooplankton abundance. A higher salinity will lead to decrease of zooplankton abundance as previously found in [37].

The obtained regression equation between TOM (X) and zooplankton abundance (Y) was $\mathrm{Y}=16.190$ $-0.274 \mathrm{x}$ with $\mathrm{R}^{2}=0.072$. This means that salinity contributes to the zooplankton abundance as much as $7.2 \%$. According to this equation, it can be explained that every increase of one unit of TOM, the abundance of zooplankton will decrease by 0.274 units. This result confirms the previous study from [38] who revealed that a higher concentration of TOM leads to a higher abundance of zooplankton in the aquatic environment.

\section{Relationship between Water Quality and the Growth of $L$. vannamei}

In the present study, the regression analysis between the temperature $(\mathrm{X})$ and the specific growth rate (SGR) of $L$. vannamei (Y) was described with the equation $\mathrm{Y}=-0.574+0.021 \mathrm{x}$. The determinant coefficient for the temperature variable from the obtained $\mathrm{R}^{2}$ was 0.410 , which means that the temperature contributes significantly to the SGR as much as $41 \%$. The temperature of brackish water affects the metabolism of L. vannamei and also the solubility of gasses including $\mathrm{O}_{2}$. Higher temperature leads to lower $\mathrm{O}_{2}$ solubility in the water, while the oxygen demand for the shrimps is higher proportionally to their metabolisms. The increase in temperature also can reduce oxygen solubility in the water and accelerates chemical reactions by two times [5].

The obtained regression equation between transparency $(\mathrm{X})$ and SGR of L. vannamei (Y) was $\mathrm{Y}=0.006+0.002 \mathrm{x}$ with $\mathrm{R}^{2}=0.258$. This means that transparency did not contribute significantly to SGR $(<50 \%)$. In this study, the obtained transparency in the shrimp pond is relatively low. This condition will alter the light penetration into the pond thus provoking the stress to the animals [39].

The obtained regression equation between salinity $(\mathrm{X})$ and SGR (Y) was $\mathrm{Y}=0.014+0.002 \mathrm{x}$ with $\mathrm{R}^{2}=0.194$. This means that salinity contributes significantly to the SGR of L. vannamei as much as $19.4 \%$. High salinity could lead to the alteration in molting process in L. vannamei, where the carapace of the animals become harder thus the energy demands for adaptation also increase [40].

In this study, the obtained regression equation between $\mathrm{pH}(\mathrm{X})$ and SGR $(\mathrm{Y})$ was $\mathrm{Y}=-0.165+0.026 \mathrm{x}$ with $\mathrm{R}^{2}=0.489$. This means that $\mathrm{pH}$ contributes significantly to the SGR as much as $48.9 \%$. pH can affect the speed of reaction and also the osmotic pressure of the organism, which eventually affect the growth of L. vannamei [41].

The regression analysis between the DO $(\mathrm{X})$ and the SGR (Y) was described with the equation $\mathrm{Y}=0.804$ $-0.110 x$. The obtained $R^{2}$ was 0.631 , which means that the DO contributes significantly to the SGR as much as $63.1 \%$. Inadequate amount of DO may cause stress to the shrimp, increasing their vulnerability to the parasites, which may lead to mortality. The DO cycle and supply in the aquatic environment will determine the capacity of the aquatic system to receive organic loads without any disruption or lethal effect to the organisms [42].

The regression analysis between the $\mathrm{NH}_{4}-\mathrm{N}(\mathrm{X})$ and the SGR (Y) was described with the equation $\mathrm{Y}=0.074-0.019 \mathrm{x}$. The obtained $\mathrm{R}^{2}$ was 0.873 , which means that the $\mathrm{NH}_{4}-\mathrm{N}$ contributes significantly to the SGR of L. vannamei as much as $87.3 \%$. High concentration of $\mathrm{NH}_{4}-\mathrm{N}$ can affect the metabolism that will lead to reduction on the shrimp appetite and inhibiting the oxygen consumption. As a result, shrimp will be limp and eventually lead to mortality [5].

The obtained regression equation between TOM (X) and SGR of L. vannamei (Y) was $\mathrm{Y}=0.063$ $-0.001 \mathrm{x}$ with $\mathrm{R}^{2}=0.749$. This means that salinity contributes to the zooplankton abundance as much as $74.9 \%$. A high accumulation in organic materials in an intensive aquaculture ponds will provoke the growth of heterotrophic microorganisms and bacterial pathogens, as well as the reduction of oxygen concentration. In the aquatic system such as shrimp pond, selfpurification may occur. However, excessive loads of organic materials may enhance the formation of toxic substances, which will eventually alter the water quality and mortality to the animals [43].

Regression analysis between $\mathrm{PO}_{4}(\mathrm{X})$ and SGR of L. vannamei (Y) produced the equation $\mathrm{Y}=$ $7.909-24.121 \mathrm{x}$ with $\mathrm{R}^{2}=0.132$. This means that $\mathrm{PO}_{4}$ contributes significantly to the SGR as much as $13.2 \%$. The concentration of $\mathrm{PO}_{4}$ can be influenced by the soil condition that may affect the productivity of the 
Table 4. Total loading value for water quality parameters, SGR, zooplankton and phytoplankton against PC1 and PC2.

\begin{tabular}{|c|c|c|}
\hline & PC 1 & PC 2 \\
\hline SGR & $\mathbf{- 0 . 3 2 8 0 1}$ & -0.17075 \\
\hline Zooplankton & -0.22504 & $\mathbf{- 0 . 4 1 3 6 9}$ \\
\hline Phytoplankton & $\mathbf{0 . 3 5 1 8 9}$ & -0.03205 \\
\hline Temperature & $\mathbf{0 . 3 4 6 8 2}$ & 0.030776 \\
\hline Transparency & $\mathbf{0 . 3 0 7 9 7}$ & 0.068198 \\
\hline pH & $\mathbf{0 . 3 3 5 8 2}$ & -0.169 \\
\hline Salinity & $\mathbf{0 . 3 3 6 0 2}$ & -0.15149 \\
\hline DO & $\mathbf{- 0 . 3 5 0 0 9}$ & 0.078744 \\
\hline $\mathrm{NH}_{4}-\mathrm{N}$ & -0.16434 & $\mathbf{0 . 4 7 4 2 4}$ \\
\hline $\mathrm{TOM}$ & -0.16721 & $\mathbf{0 . 4 7 0 4 3}$ \\
\hline $\mathrm{CO}_{2}$ & $\mathbf{- 0 . 2 9 2 8}$ & -0.22056 \\
\hline $\mathrm{PO}_{4}$ & 0.11773 & $\mathbf{0 . 4 9 0 4 2}$ \\
\hline
\end{tabular}

shrimp pond. Indeed, $\mathrm{PO}_{4}$ from the soil in the pond will dissolve into the water. The ability of soil to capture $\mathrm{PO}_{4}$ may be influenced by the clay content in the soil itself. Higher clay content in the soil can increase the ability of soil to bind $\mathrm{PO}_{4}$ [44].

Simple regression analysis revealed that the relationship between the abundance of phytoplankton (X) and the SGR of L. vannamei (Y) could be described in this following equation: $\mathrm{Y}=4.870+6.510 \mathrm{x}$ with $\mathrm{R}^{2}=0.011$. This means that phytoplankton abundance contributes significantly to the SGR as much as $1.1 \%$. The abundance of phytoplankton affects the fluctuation of DO in the aquaculture ponds. Higher abundance of plankton can decrease DO in the night time until the day time [45].
Simple regression analysis between zooplankton abundance $(\mathrm{X})$ and SGR $(\mathrm{Y})$ of $L$. vannamei revealed the positive relationship with $\mathrm{R}^{2}=0.812$ or $81.2 \%$. Brachionus sp. has been considered as marine zooplankton species with high adaptability to the change in water quality. This species often entering the shrimp ponds during the water exchange in the ponds. They developed in the ponds as the natural shrimp feed, which likely preferred by the shrimps. Indeed, the abundance of phytoplankton in the shrimp ponds really depends on the season. Several species could be highly abundant in the dry season, yet others are highly abundant in the rainy season. This fluctuation can be influenced by several factors such as temperature, $\mathrm{pH}$, nutrient concentration, light intensity, weather, presence of disease, predation by fish and zooplankton, interspecies competition and the presence of toxic algae [46].

Another statistical assessment (PCA analysis), revealed 2 main components namely $\mathrm{PCl}$ and $\mathrm{PC} 2$ (Table 4), which represent as much as 66.48 and $29.02 \%$ (Fig. 2), respectively, from the total diversity of the analyzed variables. Phytoplankton, temperature, transparency, $\mathrm{pH}$, salinity and $\mathrm{PO}_{4}$ have positive loading value on $\mathrm{PCl}$. This result demonstrated that the phytoplankton abundance increased proportionally to the increase of temperature, transparency and $\mathrm{pH}$ as well as nutrient enrichment (phosphate). On the other hand, $\mathrm{CO}_{2}$ had negative loading value on $\mathrm{PC} 1$, indicating that the augmentation of $\mathrm{CO}_{2}$ has an impact on the depletion of phytoplankton abundance.

Our PCA analysis showed that zooplankton had the highest loading value on PC2 as compared to PC1 with negative value. Additionally, on similar PC2 component, $\mathrm{NH}_{4}-\mathrm{N}$ and $\mathrm{TOM}$ had positive loading value. This indicates that high content of $\mathrm{NH}_{4}-\mathrm{N}$ and TOM could decrease the abundance of zooplankton.

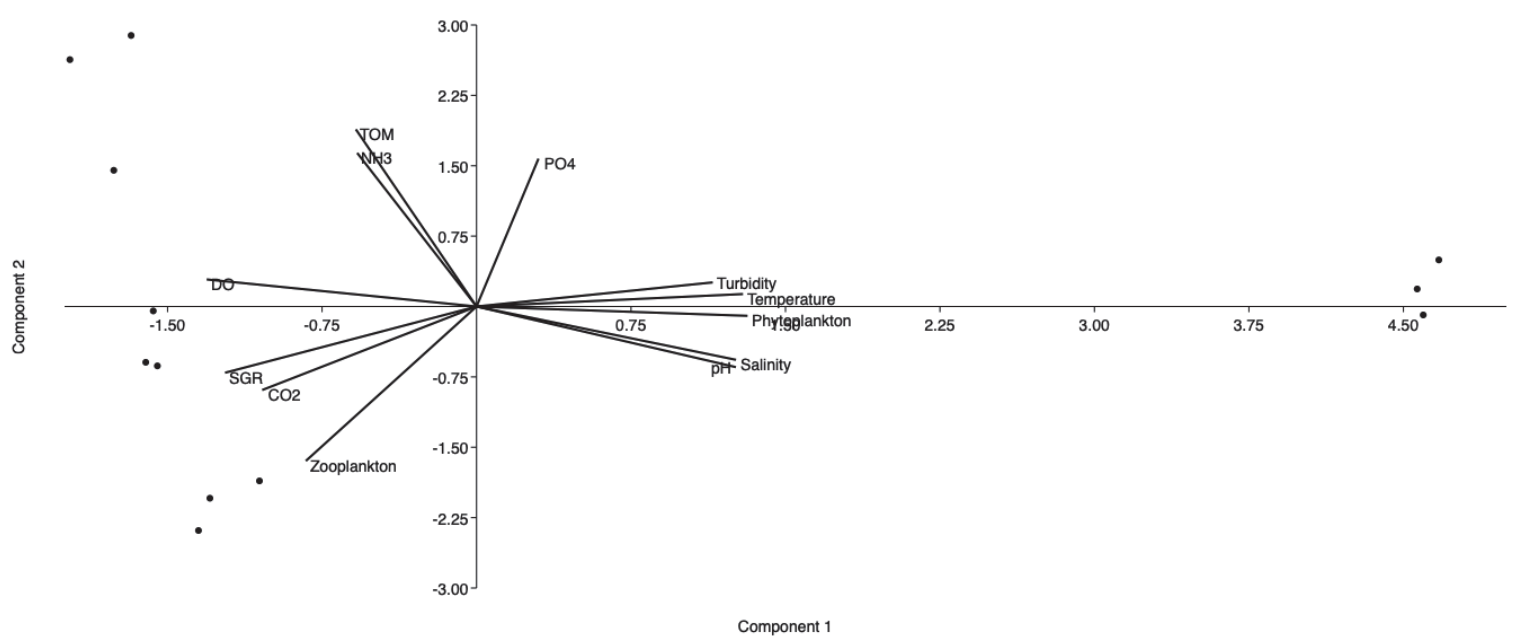

Fig. 2. Biplot Ordination of Principal Component Analysis (PCA). 
However, based on loading value on PC1, the phytoplankton abundance correlates positively with the concentration of DO. Similar trend was found in SGR and $\mathrm{DO}$ on PC1 where the negative loading values of these two parameters were observed.

\section{Conclusions}

In the present study, the water quality parameters in the shrimp intensive ponds with optimum value are temperature, $\mathrm{DO}, \mathrm{NO}_{2}, \mathrm{TOM}$ and $\mathrm{PO}_{4}$. On the other hand, other parameters such as transparency, $\mathrm{pH}$, salinity, $\mathrm{NH}_{4}-\mathrm{N}$ and $\mathrm{NO}_{3}$ were not in optimum range. Based on the results of regression analysis, the parameters that had the most impact on the abundance of phytoplankton and zooplankton were salinity and temperature, while the parameters that had the most impact on L. vannamei growth were ammonia. According to the plankton abundance, both phytoplankton and zooplankton, the status of aquatic in the intensive aquaculture facility of Laboratory Fisheries and Marine Science Probolinggo can be categorized as highly abundant. This study reveals that water quality significantly affects the plankton dynamics and the SGR of $L$. vannamei, supported by the significant value of $\mathrm{R}^{2}$ in regression and PCA analysis.

\section{Acknowledgments}

This research was financially supported by Doctor Associate professor Researcher Grant (Hibah Doktor Lektor Kepala) 2020 Number: 2524/UN10.F06/KS/2020 LPPM Universitas Brawijaya.

\section{Conflict of Interest}

The authors declare no conflict of interest

\section{References}

1. ARSAD S., AFANDY A., PURWADHI A.P., MAYA B., SAPUTRA D.K., BUWONO N.R. Studi Kegitan Budidaya Pembesaran Udang Vaname (Litopenaeus vannamei) dengan Penerapan Sistem Pemeliharaan Berbeda. Jurnal Ilmiah Perikanan dan Kelautan, 9 (1), 1, 2017.

2. MULTAZAM A.E., HASANUDDIN Z.B. Sistem monitoring kualitas air tambak udang vaname. Jurnal IT Media Informasi STMIK Handayani Makassar, 8 (2), 118, 2017.

3. PIRZAN A.M., UTOJO Pengaruh variabel kualitas air terhadap produktivitas udang vaname (Litopenaeus vannamei) di kawasan pertambakan Kabupaten Gresik, Jawa Timur. Majalah Ilmiah Biologi Biosfera: A Scientific Journal, 30 (3), 126, 2013.

4. MUSA M., MAHMUDI M., ARSAD S., BUWONO N.R. Feasibility study and potential of pond as silvofishery in coastal area: Local case study in Situbondo. Regional Studies in Marine Science, 33 (100971), 2020.

5. PUTRA F.R, MANAN A. Monitoring Kualitas Air pada Tambak Pembesaran Udang Vannamei (Litopenaues vannamei) di Situbondo, Jawa Timur. Jurnal Ilmiah Perikanan dan Kelautan, 6 (2), 137, 2014.

6. ODUM E.P. Basic Ecology (Dasar-dasar Ekologi). Universitas Gajah Mada Press. Yogyakarta. 1993.

7. SOUMIA A. Phytoplankton Manual. Unesco: International Institute for Educational Planning. Perancis, 1978.

8. ODUM E.P. Fundamental of Ecology. Third Ed. W. B. Saunders Company. Philadelphia. 574, 1971.

9. PERATURAN MENTERI, KELAUTAN, PERIKANAN Republik Indonesia Nomor 75 Tahun 2016 Tentang Pedoman Umum Pembesaran Udang Windu (Penaeus Monodon) dan Udang Vaname (Litopenaeus Vannamei), 2016.

10. ARSAD S., ZSALZSABIL N.A.N., PRASETIYA F.S., SAFITRI I., SAPUTRA D.K., MUSA M. Komunitas Mikroalga Perifiton pada substrat berbeda dan perannya sebagai bioindicator perairan. Saintek Perikanan, 15 (1), 73, 2019.

11. KORDI K.M., GHUFRAN H., TANCUNG A.B. Pengelolaan Kualitas Air dalam Budidaya Perairan. Rhineka Cipta. Jakarta, 2007.

12. RAHARJO E.I., FARIDA, Sukmayani Analisis kesesuain perairan di Sungai Sambas Kecamatan Sebawi Kabupaten Sambas untuk usaha budidaya perikanan. Jurnal Ruaya, 4 (2), 21, 2016.

13. SULISTIONO M.F., RAHARDJO, SIMANJUNTAK C.P., ZAHID A. Komunitas ikan di Telaga Warna, Jawa Barat. Jurnal Iktiologi Indonesia, 10 (2), 191, 2017.

14. KRISTIAWAN D., WIDYORINI N. Haeruddin Hubungan total bakteri dengan kandungan bahan organik total di Muara Kali Wiso, Jepara. Management of Aquatic Resources Journal, 3 (4), 24, 2014.

15. ARFIATI D., PRAMUDYO D.R., PUSPITASARI A.W. Analisis total bahan organik pada air proses budidaya ikan mas (Cyprinus carpio) Di UPBAT Punten, Kota Batu, Jawa Timur. Prosiding Seminakel. 1 (1), 63, 2019.

16. MAKMUR H.S., SUWOYO, FAHRUR M., SYAH R. Pengaruh Jumlah Titik Aerasi pada Budidaya Udang Vaname, Litopenaeus vannamei. Jurnal Ilmu dan Teknologi Kelautan Tropis, 10 (3), 727, 2018.

17. KOMARAWIDJAJA W. Pengaruh Perbedaan Dosis Oksigen Terlarut (DO) pada Degradasi Amonium Kolam Kajian Budidaya Udang. Jurnal Hidrosfer, 1 (1), 32, 2006.

18. CORRELL D.L. The Role of Phosphorus in the Eutrophication of Receiving Waters: A Review. J. Environ. Qual., 27, 261, 1998.

19. MUSA M., ARSAD S., AGHARID N.K., DARMAYANTI $S$. The effect of water quality on plankton about dynamics and its relationship to the spe-cific growth of vaname shrimp. Presented on Seminar Nasional virtual Riset dan Inovasi Kelautan Untuk Pengelolaan Sumber Daya Pesisir dan Laut di Era Normal Baru. 27 July, 2020.

20. SURYANTO A.M.H., UMI H.S. Pendugaan status trofik dengan pendekatan kelimpahan fitoplankton dan zooplankton di Waduk Sengguruh, Karangkates, Lahor, Wlingi Raya dan Wonorejo Jawa Timur. Jurnal Ilmiah Perikanan dan Kelautan, 1 (1), 7, 2009.

21. RAHMATULLAH R., ALI M.S., KARINA S. Keanekaragaman dan dominansi plankton di Estuari Kuala Rigaih Kecamatan Setia Bakti Kabupaten Aceh Jaya. Jurnal Ilmiah Mahasiswa Kelautan Perikanan Unsyiah, 1 (3), 325, 2016. 
22. INDRAYANI N., ANGGORO S., SURYANTO A. Indeks trofik-saprobik sebagai indikator kualitas air di Bendung Kembang Kempis Wedung, Kabupaten Demak. Management of Aquatic Resources Journal, 3 (4), 161, 2014.

23. PIRZAN A.M., UTOJO, ATMOMARSO M., TJARONGE M., TANGKO A.M. Hasnawi Potensi lahan budi daya tambak dan laut di Kabupaten Minahasa, Sulawesi Utara. Jurnal Penelitian Perikanan Indonesia, 11 (5), 43, 2005.

24. KREBS Ecology. The Experimental Analysis of Distribution and Abundance. Third Edition. Harper and Row Distribution, New York. 289, 1978.

25. RAKHFID A., HALIDA W.O., ROCHMADY Fendy Aplikasi Probiotik untuk Pertumbuhan dan Kelangsungan Hidup Udang vaname (Litopenaues vannamei) pada padat tebar berbeda. Jurnal Akuakultur, Pesisir dan Pulau-Pulau Kecil, 2 (2), 41, 2018.

26. ISKANDAR R., ELRIFADAH PERTUMBUHAN Efisiensi Pakan Ikan Nila (Oreochromis niloticus) yang diberi Pakan Buatan Berbasis Kiambang. Zira'ah, 40 (1), 184, 2015.

27. PRATIWI E.D., KOENAWAN C.J., ZULFIKAR A. Hubungan kelimpahan plankton terhadap kualitas air di Perairan Malang Rapat Kabupaten Bintan Provinsi Kepulauan Riau. Jurnal Umrah, 28, 1, 2015.

28. HASANA A.N., RUKMINASARI N., SITEPU F.G. Perbandingan kelimpahan dan struktur komunitas zooplankton di Pulau Kodingareng dan Lanyukang, Kota Makassar. Jurnal Administrasi dan Kebijakan Kesehatan Indonesia, 24 (1), 14, 2014.

29. RADIARTA I.N. Hubungan antara distribusi fitoplankton dengan kualitas perairan di Selat Alas, kabupaten Sumbawa, Nusa Tenggara Barat. Bumi Lestari Journal of Environment, 13 (2), 234, 2013.

30. KASRY A., SUMIARSIH E., HERIYANTO Kesuburan perairan Waduk Nagedang ditinjau dari kosentrasi klorofil-a fitoplankton Desa Giri Sako Kecamatan Logas Tanah Darat Kabupaten Kuantan Singingi Provinsi Riau. Berkala Perikanan Terubuk, 37 (2), 48, 2009.

31. BAROKAH G.R., PUTRI A.K., GUNAWAN G. Kelimpahan fitoplankton penyebab hab (Harmful Algal Bloom) di Perairan Teluk Lampung pada Musim Barat dan Timur. Jurnal Pascapanen dan Bioteknologi Kelautan dan Perikanan, 11 (2), 115, 2017.

32. RASMIATI E., NEDI S., AMIN B. Analisis kandungan bahan organik total dan kelimpahan fitoplankton di Perairan Muara Sungai Dumai Provinsi Riau. Disertasi. Fakultas Perikanan dan Kelautan. Universitas Riau, 2017.

33. FITRIALISMA Y., SYAMSWISNA, YENI L.F. Penyusunan perangkat pembelajaran pada sub materi alga berdasarkan struktur komunitas fitoplankton di Siantan Hilir. Jurnal Pendidikan dan Pembelajaran Khatulistiwa, 3 (2), 1, 2014.

34. HARIYATI R. Distribusi dan keanekaragaman zooplankton di Waduk Jatibarang Kodya Semarang. Bioma: Berkala Ilmiah Biologi, 19 (2), 83, 2017.
35. STEPHANI S., YULIATI Y., EFAWANI E. Diversity of zooplankton in the Kandis River Karya Indah Village, Tapung Sub-Regency, Kampar Regency, Riau Province. Jurnal Onine Mahasiswa, 1 (2), 1, 2014.

36. YULIANA, AHMAD F. Komposisi jenis dan kelimpahan zooplankton di perairan Teluk Buli, Halmahera Timur. Jurnal Ilmiah Agribisnis dan Perikanan, 10 (2), 44, 2017.

37. NOVIA R., ADNAN, RITONGA I.R. Hubungan parameter fisika-kimia perairan dengan kelimpahan plankton di Samudera Hindia bagian Barat Daya. Depik, 5 (2), 67, 2016.

38. LUKMAN Danau Lindu Keteduhan yang Merindu. LIPI Press. Jakarta. 61 hlm, 2007.

39. PASONGLI H., DIRAWAN G.D., SUPRAPTA Zonasi Kesesuaian Tambak untuk Pengembangan Budidaya Udang Vaname (Panaeus vannamei) Pada Aspek Kualitas Air di Desa Todowongi Kecamatan Jailolo Kabupaten Halmahera Barat. Jurnal Bioedukasi, 3 (2), 324, 2015.

40. ANITA A.W., AGUS M., MARDiANA T.Y. Pengaruh Perbedaan Salinitas Terhadap Pertumbuhan dan Kelangsungan Hidup Larva Udang Vanname (Litopenaues vannamei) PL-13. Pena Akuatika, 16 (1), 12, 2017.

41. EFFENDI H., UTOMO B.A., DARMAWANGSA G.M., KARO-KARO R.E. Fitoremediasi Limbah Budidaya Ikan Lele (Clarias sp.) dengan Kangkung (Ipomea aquatica) dan Pakcoy (Brassicarapa chinensis) dalam sistem resirkulasi. Ecolab, 9 (2), 47, 2015.

42. YUMAME R.Y., ROMPAS R., PANGEMANAN N.P.L. Kelayakan Kualitas Air Kolam di Lokasi Pariwisata Embung Klamalu Kabupaten Sorong Provinsi Papua Barat. Budidaya Perairan. 1 (3), 56 hal, 2013.

43. PARLINA I., NASIRIN, IHSAN I.M., SUHARYADI, SYAPUTRA A., SRI BUDIANA, HANIF M. Perbandingan Pengelolaan Lingkungan pada Budidaya Udang Vaname (Litopenaeus vannamei) dengan Aplikasi Anorganik Chelated dengan Probiotik. Jurnal Teknologi Lingkungan, 19 (1), 33, 2018.

44. MUSTAFA A., ATHIRAH A. Aplikasi Analisis Jalur dalam Penentuan Pengaruh Kualitas Tanah dan Air terhadap Produksi Total Tambak di Kabupaten Demak, Provinsi Jawa Tengah. Jurnal Kelautan Nasional, 9 (2), 65, 2014.

45. RETNOSARI D., REJEKI S., SUSILOWATI T., ARIJATI R.W. Laju Filtrasi Bahan Organik oleh Kerang Hijau (Perna viridis) Sebagai Biofilter Serta Dampaknya Terhadap Pertumbuhan dan Kelulushidupan Udang Windu (Penaeus monodon). Jurnal Sains Akuakultur Tropis, 3 (1), 36, 2019.

46. UTOJO, MUSTAFA A. Struktur Komunitas Plankton pada Tambak Iintensif dan Tradisional Kabupaten Probolinggo, Provinsi Jawa Timur. Jurnal Ilmu dan Teknologi Kelautan Tropis, 8 (1), 269, 2016. 